\title{
5 Weeds, Diseases, Insect Pests, and Tri-Trophic Interactions in Tropical Agroforestry
}

\author{
G. Sileshi, Götz Schroth, Meka R. Rao, and H. Girma
}

\section{CONTENTS}

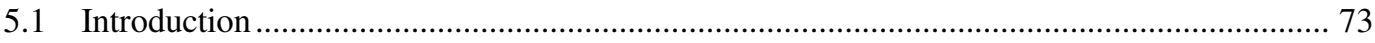

5.2 Partitioning the Complexity of Pest Interactions .............................................................. 75

5.2.1 Interactions Between the Plant Community, Herbivores, and their

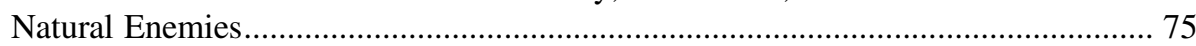

5.2.2 Interactions Between Herbivores and Plant Pathogens ........................................ 78

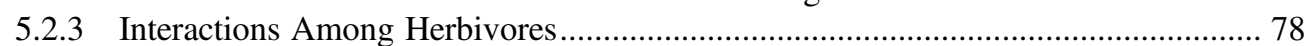

5.3 Interactions in Selected Agroforestry Practices .............................................................. 79

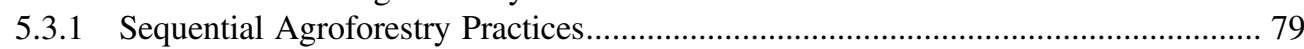

5.3.1.1 Rotational Woodlots and Improved Fallows............................................. 79

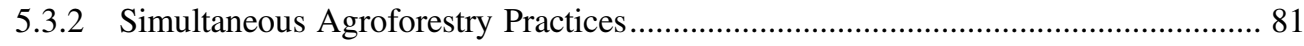

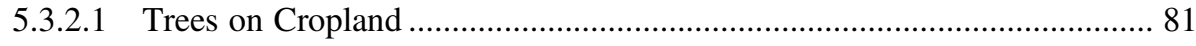

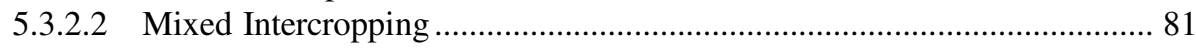

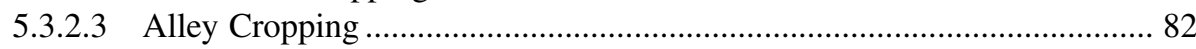

5.3.2.4 Multistrata Agroforestry Systems ........................................................... 84

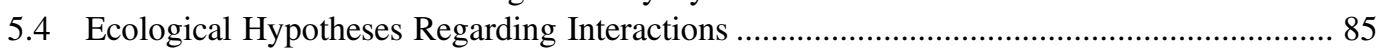

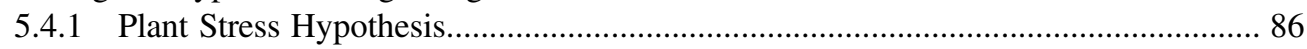

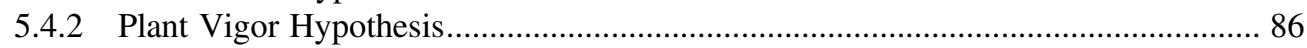

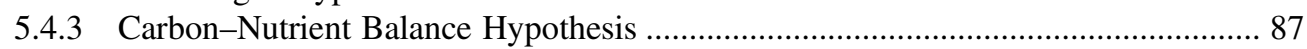

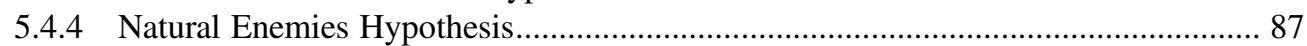

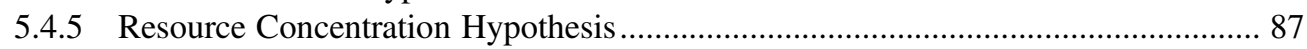

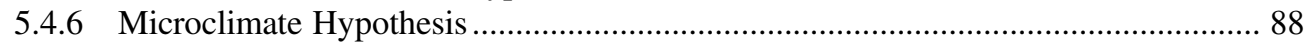

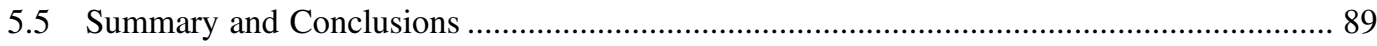

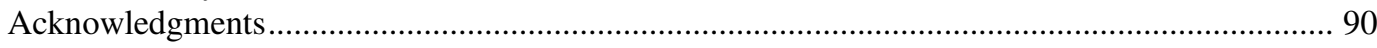

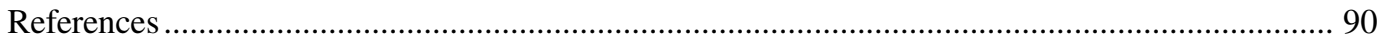

\subsection{INTRODUCTION}

Under the International Plant Protection Convention, a pest is defined as any species, strain, or biotype of plant, animal, or pathogenic agent injurious to plants or plant products (ISPM, 2006). The coverage of this definition includes weeds and other species that have indirect effects on plants. This definition also applies to the protection of wild flora that contribute to the conservation of biological diversity. Unless otherwise stated, throughout this chapter the term "pest" refers to weedy plants and parasitic higher plants, plant pathogenic organisms (viruses, bacteria, mycoplasma, fungi), plant parasitic or pathogenic nematodes, arthropods (herbivorous mites and insects), and vertebrate pests (herbivorous birds and mammals) that affect trees and associated crops in agroforestry. 
Weeds may be classified as ruderals (annual or biennial plants that primarily infest waste places), argestals (annual or biennial weeds of cultivated lands), and environmental weeds (invasive alien species). Weeds compete with trees and crops for water, light, and nutrients. Many weed species also serve as alternative hosts of plant pathogenic organisms and nematodes. Exotic tree species used in agroforestry can also become invasive and affect ecosystem functions and biodiversity. According to a recent estimate (Richardson, 1998), out of over 2000 species used in agroforestry, some 25 species (1\%) are invasive. These include Acacia (8 spp.), Prosopis (3 spp.), Casuarina (2 spp.), Leucaena leucocephala, Sesbania bispinosa. It must be noted here that not all alien species are invasive, and not all invasive species may be economically important. Transformer species-a subset of invasive plants that change the character, condition, form, or nature of a natural ecosystem over a substantial area-have profound effects on ecosystem functions and biodiversity and are invasive (Richardson, 1998).

A disease can be defined as any physiological disturbance of the normal functioning of a plant as a result of a detrimental interaction between the pathogen, the environment, and the host (Agrios, 1988). Diseases affect the production and utilization of trees and crops by reducing the health of the plant and directly reducing yield, quality, or storage life. Plant parasitic nematodes mostly affect plants by inhibiting root growth, and hence overall plant development, and this usually results in poor crop performance or complete failure. Many plant parasitic nematodes also interact with other microorganisms such as viruses, bacteria, and fungi in the development of disease complexes (Kleynhans et al., 1996). Herbivorous mites and insects can physically feed on various parts of the tree, crop, or both, and also transmit diseases.

In the tropics, weeds, diseases, and insect pests are estimated to account for 13\%,13\%, and 20\% of losses, respectively (Oerke et al., 1994). Weed control takes over 50\% of the total labor needed to produce a crop. Pests have been cited as one of the factors diminishing the benefits from tropical agroforestry (Mchowa and Ngugi, 1994; Karachi, 1995; Rao et al., 2000). Unless the biological constraints imposed by pests are removed, the potential benefits of agroforestry in terms of increased capture and efficient use of resources cannot be translated into economic benefits (Ong and Rao, 2001). If the current enthusiasm of farmers for testing and eventually adopting the various agroforestry practices is to be sustained, it is essential to know how this practice affects pest populations and their natural enemies.

Although the relevance of pest interactions with agroforestry practices has been recognized many years ago (Huxley and Greenland, 1989), very few detailed studies of their influence on treecrop interactions exist. There seems to be more focus on population ecology of selected pest species at the expense of ecosystem ecology. In fact, there exist certain general misconceptions, which hold that trees have no or fewer pests and that diversity based on trees reduces pest problems in agroforestry (Desaeger et al., 2004). This has hindered progress in the understanding of tri-trophic interactions in agroforestry. Even in the more recent books on agroforestry (Schroth and Sinclair, 2003; Nair et al., 2004; van Noordwijk et al., 2004), there is little, if any, mention of the effects of tree-crop interactions on pests and their natural enemies. In the recent reviews, Day and Murphy (1998) and Rao et al. (2000) dealt mainly with insect pests affecting agroforestry trees and their management. Schroth and coworkers (2000) dealt with insect pests and diseases in agroforestry systems of the humid tropics. The review by Gallagher et al. (1999) and Ong and Rao (2001) focused on managing tree-crop interactions in relation to weeds. Desaeger et al. (2004) dealt with nematodes and other soil-borne pathogens. The review on the effect of trees on abundance of natural enemies (Dix et al., 1995) focused on agroforestry systems of the temperate zone.

Though complex interactions are known to occur between various categories of pests (e.g., weeds, pathogens, nematodes, insects, etc.), the nature of such interactions are poorly understood and little quantified in tropical agroforestry (Hitimana and McKinlay, 1998). This work is the first attempt to draw together information on the different categories of pests and natural enemies, and apply the knowledge to the challenges of pest management in tropical agroforestry. In this chapter, an extensive review of literature pertinent to tree-crop interactions and pest risks in 
agroforestry was conducted. In view of the vast number of tree and crop species used in agroforestry and numerous pest species, a complete treatment of the subject matter is beyond the scope of this chapter. Only a selection of the most widely used agroforestry systems are given here as examples, and typical cases are examined. The objective is to analyze the factors that influence pest incidence in the light of existing ecological hypotheses. In the discussions, more emphasis has been on information generated after the recent reviews by Day and Murphy (1998), Rao et al. (2000), and Schroth et al. (2000). This is intended to fill the gaps in knowledge and complement the existing reviews.

\subsection{PARTITIONING THE COMPLEXITY OF PEST INTERACTIONS}

In agroforestry systems, plants have close relations with abiotic and biotic components in the community. According to Ong et al. (2004), the net effect of one plant component on another can be expressed as:

$$
I=F+C+M+P+L+A,
$$

where

$I$ is the overall interaction

$F$ is effects on chemical, physical, and biological soil fertility

$C$ is competition for light, water, and nutrients

$M$ is effect on microclimate

$P$ is effect on pests

$L$ is soil conservation

$A$ is allelopathic effects

Many of these effects are interdependent and cannot be experimentally estimated independently of one another. This means that when studying the effect of pests in agroforestry, we cannot ignore the effects inter alia of soil fertility, competition, or microclimate.

Pests of an agroforestry system are essentially the pests of its components (the crops and woody perennials), and their dynamics is governed by the complexity and degree of interaction between the crop, tree, and the composition of other plant communities such as weeds. Direct interactions between trees and crops for growth resources may exercise a strong influence on pests and natural enemies of either or both components of the system (Table 5.1). In the following discussion, the manner in which each component affects the other in terms of pest populations is briefly summarized. A simplified model of potential interactions between the plant community, herbivores, pathogens, and natural enemies in a simultaneous agroforestry practice is presented in Figure 5.1.

\subsubsection{Interactions Between the Plant Community, Herbivores, and their Natural Enemies}

The plant community (or producers), including the trees, crops, and weeds, constitute the first trophic level. Each plant species may be attacked by a wide range of herbivores (i.e., primary consumers), which constitute the second trophic level. Herbivorous species in turn are attacked by natural enemies (i.e., secondary consumers), which constitute the third trophic level. Natural enemies include predatory arthropods (e.g., insects, predaceous mites, spiders, scorpions, centipedes, etc.) and vertebrates (e.g., insectivorous birds and mammals), parasitic insects (i.e., parasitoids), and pathogenic bacteria, viruses, fungi, protozoa, and nematodes, which play a significant role in the population dynamics of pests of agroforestry (Sileshi et al., 2001).

The interactions that occur between the plants, herbivores, and their natural enemies are called tri-trophic interactions. The plant community may affect these interactions in a variety of ways, as depicted in Figure 5.1 and Table 5.1. For instance, trees through shading or their physical presence may directly influence the migration, host location, and feeding of insect pests of the crop in 


\section{TABLE 5.1}

\section{Summary of Tree-Crop Interactions and their Consequences on Pests and Diseases in Major Groups of Agroforestry Systems}

\section{Process}

Sequential systems

Simultaneous systems

addition to acting as refuge for natural enemies. Trees can also influence pest incidence by acting as alternative hosts of a crop pest or vector of a pathogen. Trees, through their indirect effects on the nutrition of the crop, may also influence demographic parameters of crop pests such as natality, longevity, and mortality. This in turn may trigger changes in the migration, host location, feeding, and demographic patterns of natural enemies. Trees may also cause shading and reduce air circulation, leading to high humidity and an increase in disease incidence. A detailed knowledge of tri-trophic interactions associated with a given pest or pest complex is required if refuge for natural enemies are to be conserved or established.
Reduction of annual and perennial weeds

Weed seed-bank depleted

Striga population and its seed-bank are reduced Reduction of weed populations

Tree species becomes an environmental weeds

Increase costs of control

Increased pests damage in adjacent crop fields

Increased crop vigor to withstand some pests

Increased vigor inducing susceptibility to other pests

Reduction in insect, disease and nematode damage on subsequent crops

Increased pest damage on subsequent crops

Increased soil-borne disease populations

Reduction of pest problems in adjacent crop fields

Reduced vigor inducing susceptibility to pests attack

Reduction of pest problems in adjacent crop

fields

Reduction of pest colonization

Increased crop vigor

Buildup of pests and pathogens

Increased pest damage on crops

Reduction of shade sensitive weeds

Increase in pest problems

Buildup of some disease
Tree canopy and leaf litter keeping the ground covered for most part of the year 


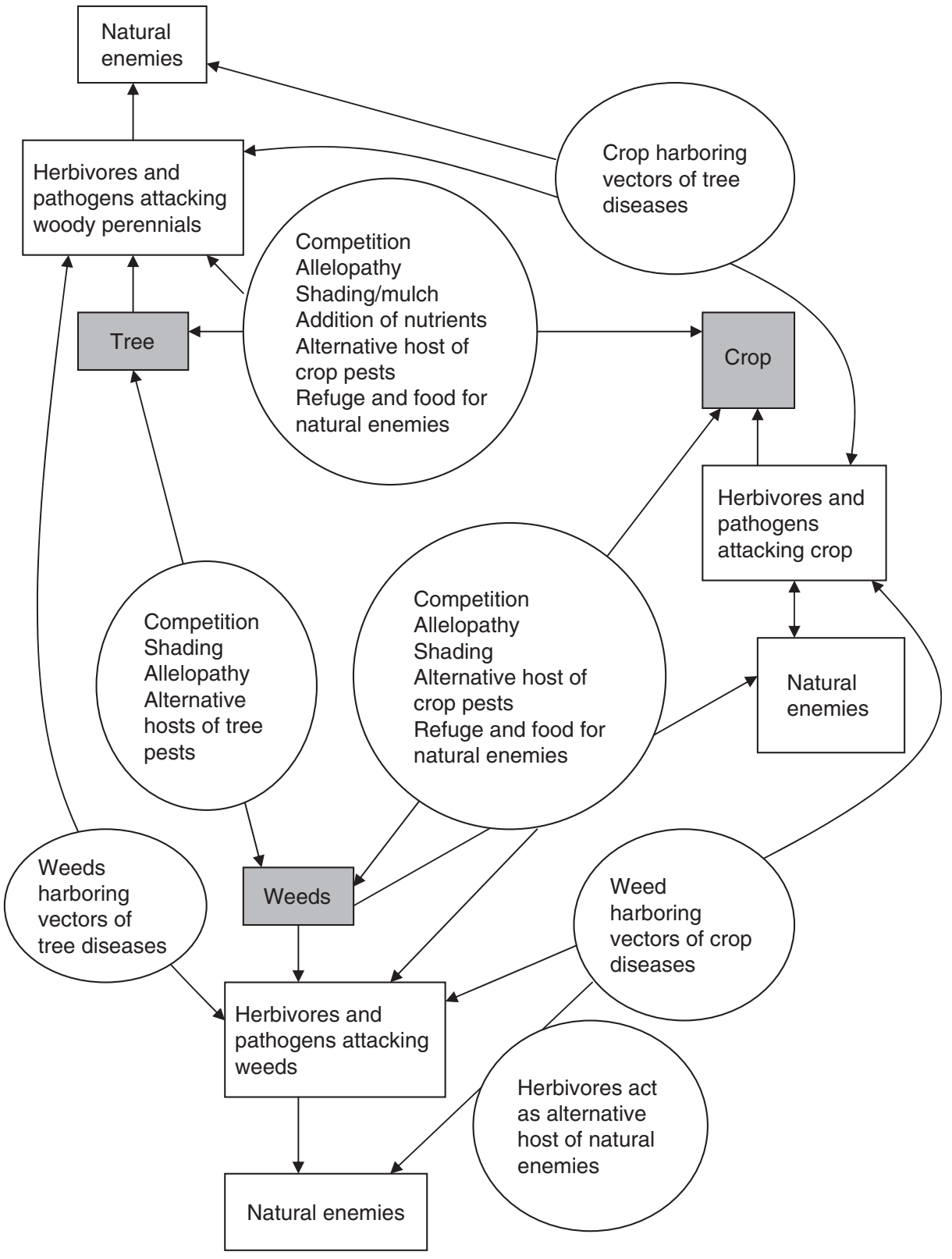

FIGURE 5.1 Potential interactions between the plant community, herbivores, pathogens and natural enemies in a simultaneous agroforestry practice.

Weeds, in addition to competing with the tree and crop components, may also act as alternative hosts of pests of the tree or crop components. For instance, in western Kenya, Striga hermonthica, a parasitic weed of cereals, is a good host for root-knot nematodes, which attack agroforestry species such as Sesbania sesban and Tephrosia vogelii (Desaeger et al., 2004). Cultivated ground cover plants and weeds (e.g., in orchards) can increase the heterogeneity of the habitat, alter the quality and quantity of bio-resources, and regulate ecological niches of various species in the community. Such plants can provide a variety of resources for predators and parasitoids, including shelter, food, and information on the location of their herbivorous prey (Bugg and Waddington, 1994; Liang and 
Huang, 1994). Liang and Huang (1994) reported that the weed Ageratum conyzoides, growing in citrus orchards, plays an important role in stabilizing populations of the predatory mites (Ambleyseius spp.), which are effective natural enemies of the citrus red mite (Panonychus citri). Understory vegetation can also sustain significantly higher generalist predators such as lady beetles, ground beetles, hover flies, mirid bugs, and lacewings in orchards than clean-weeded orchards (Bugg and Waddington, 1994). Many aphids that colonize weeds can play an important role as reservoirs of polyphagous natural enemies such as lady beetles, hover flies, and lacewings.

\subsubsection{Interactions Between Herbivores and Plant Pathogens}

The manner in which herbivores interact with plant pathogenic organisms include: (1) acting as vectors, (2) wounding agents, (3) host modifiers, (4) rhizosphere modifiers, and (5) resistance breakers (Agrios, 1988). Desaeger et al. (2004) provide specific examples of such interactions between nematodes and soil-borne pathogens. Homopterous insects, beetles, and mites vector viral, bacterial, and fungal diseases, which cause substantially greater losses than those caused by the direct feeding injury by the insects. For instance, the green peach aphid (Myzus persicae) is known to be a vector of more than 180 virus diseases. The cotton aphid (Aphis gossypii) transmits more than 80 kinds of virus diseases. The black citrus aphid (Toxoptera citricidus) is a vector of virus diseases of coffee, citrus tristeza virus, citrus infectious mottling virus, and little leaf and lemon-ribbing virus of lemon (Michaud, 1998; EPPO, 2006). Some xylem fluid-feeding leafhoppers also transmit the bacterial plant pathogen Xylella fastidiosa, which induces diseases of grapevines (e.g., Pierce's disease) and citrus (citrus variegated chlorosis), and also other diseases of coffee and stone fruits. Citrus-variegated chlorosis transmitted by the glassy-winged sharpshooter (Homalodisca coagulata) has now expanded throughout many citrus-growing areas of South America (Redak et al., 2004).

One of the classic examples of a disease vectored by beetles is the Dutch elm disease, a vascular-wilt fungus, Ophiostoma (Ceratocystis) ulmi, carried from an infected tree to a healthy one by bark beetles of the genus Scolytus (Agrios, 1988). Recently, the weevil Pissodes nemorensis has been reported as a vector of and wounding agent of the pitch canker fungus (Fusarium circinatum) and Diplodia pinea causing dieback on pines (Pinus species) (Gebeyehu and Wingfield, 2003). The bean beetle Ootheca mutabilis, which attacks Se. sesban, also transmits cowpea mosaic virus, one of the commonest viral diseases of cowpea reducing yields by up to 95\% (van Kammen et al., 2001). Arthropods that transmit plant diseases may vector plant pathogens to and from the tree, crop, and weed hosts in agroforestry (Figure 5.1).

\subsubsection{Interactions Among Herbivores}

Interactions also occur among herbivores in the form of competition and mutualism. Competition is defined as the interaction between individuals, brought about by a shared requirement for a resource in limited supply, and leading to a reduction in the survivorship, growth, and reproduction of the competing individuals (Speight et al., 1999). Generally, competition can occur among individuals of the same species (intraspecific) or members of different species (interspecific). Damage by one herbivore species could influence populations of a second species through changes in plant quality, even if the herbivores lived at different times of the year. West (1985) demonstrated that spring defoliation by caterpillars of two Lepidoptera, Operophthera brumata (Geometridae) and Tortrix viridana (Tortricidae), on oak leaves can reduce leaf nitrogen content, which adversely affects the survival of the Lepidopteran leaf-miner Phyllonorycter (Gracillaridae) and aphids later in the season.

Mutualism is a type of symbiosis in which two or more organisms from different species live in close proximity to one another and rely on one another for nutrients, protection, or other life functions. For example, many ants are known to tend homopterous pests such as aphids, mealy bugs, and scale insects, where the ants protect these insects from predation and parasitism. In turn, 
the ants get honey dew from their hosts. On the other hand, ants are predators and may well have a positive effect as biocontrol agents. In shade coffee production systems Vandermeer and coworkers (2002) demonstrated that ants (Azteca sp.) can have potential as pests through their positive effect on scale insects, but also have potential as biological control agents through their effect on other herbivores.

\subsection{INTERACTIONS IN SELECTED AGROFORESTRY PRACTICES}

Section 5.3.1 presents the characteristics of the various agroforestry practices as they affect the occurrence and development of weeds, insect pests, and diseases. Agroforestry systems were broadly grouped into sequential (rotational) and simultaneous systems (Rao et al., 1998). The presentation was structured from the simplest to the more complex tree-crop associations to facilitate comprehension of the interactions.

\subsubsection{Sequential Agroforestry Practices}

\subsubsection{Rotational Woodlots and Improved Fallows}

In the rotational woodlot system, food crops are intercropped with leguminous trees during the first 2-3 years. Then the trees are left to grow, harvested in about the fifth year, and food crops are replanted (Otsyina et al., 1996). The food crops grown following the tree harvest are expected to benefit from improved soil conditions by the woodlot species. Improved fallows, on the other hand, consist of deliberately planted species - usually legumes with the primary purpose of fixing nitrogen as part of a crop-fallow rotation (Mafongoya et al., 1998; Sanchez, 1999). The legumes can be planted as either single species or mixed stands. Compared with single-species fallows, mixedspecies fallows are believed to increase the biodiversity and sustainability of the fallow system, provide insurance against failure, produce multiple products, improve utilization of available plant growth resources, and reduce buildup of pests (Gathumbi, 2000; Sileshi and Mafongoya, 2002).

Rao et al. (1998) recognized three distinct phases based on the major soil changes that occur in the rotation of tree fallows by crops. These changes may directly or indirectly affect the populations of weeds, pathogens, and insect pests affecting the subsequent crop (Schroth et al., 2000; Sileshi and Mafongoya, 2002, 2003). One of the significant impacts of these changes in vegetation cover is on the parasitic weeds (Striga spp.), which are widespread in most parts of sub-Saharan Africa and cause annual cereal yield losses estimated between $\$ 7$ and 13 billion (Annon, 1997). In two separate studies conducted in eastern Zambia (Sileshi et al., 2006), rotational fallows of Se sesban significantly reduced incidence of Striga asiatica on subsequent maize compared with continuously cropped monoculture maize, or that grown after a traditional bush fallow. This effect of the Se sesban fallow persisted through three consecutive cropping cycles. Similarly in Kenya, Se. sesban reduced the number of St. hermonthica seeds in the soil by $34 \%$, whereas in monoculture maize plots the Striga populations increased over the same period by $11 \%$ (ICRAF, 1993). The effect of Se. sesban on Striga was due to the combined effects of Se. sesban causing suicidal germination of St. hermonthica (i.e., a "trap crop" effect) and improving soil inorganic N, which is known to be detrimental to Striga (Gacheru and Rao, 1998).

Tree fallows also reduce the incidence of weeds in general including the perennial grasses such as spear grass (Imperata cylindrica) (Garrity, 1997). In Sri Lanka, weed populations were lower by $42 \%$ and 54\% in maize planted in improved fallow of Crotolaria juncea and Tithonia diversifolia than in a natural fallow (Sangakkara et al., 2004). In Nigeria, 3 years of planted fallows of Dactyladenia barteri in Nigeria caused 36\% decrease in the weed seed-bank relative to the cropped field, whereas the same duration of bush fallow increased the weed seed-bank by $31 \%$ (Akobundu and Ekeleme, 2002). Studies in Zambia (Sileshi and Mafongoya, 2003; Sileshi et al., 2006) have demonstrated that some legume fallows can reduce the infestation of maize by arable weeds. In one 
study (Sileshi and Mafongoya, 2003), total weed biomass in maize grown after a natural fallow was six times higher than that grown after pure Se. sesban and pigeon pea fallows. The weed biomass was correlated negatively with leaf litter indicating that the reduction is due to smothering of the weeds through initial suppression of aboveground weed growth, and the thick mulch layer formed by the leaf litter from the fallow trees subsequently depleting the weed seed-bank (Sileshi and Mafongoya, 2003). Many fallow species release a wide range of compounds, commonly referred to as allelochemicals, which can inhibit weed seed germination or reduce weed vigor. Legume covercrop residues in the course of decomposition release volatile organic compounds with potential herbicidal properties (Gallagher et al., 1999).

Rotational fallows have also been shown to affect plant-parasitic nematodes that attack crops. Some fallow species (e.g., Sesbania, pigeon pea, Tephrosia, and Acacia) are hosts for plant parasitic nematodes such as Meloidogyne and Pratylenchus spp. (Page and Bridge, 1993; Duponnois et al., 1999; Desaeger and Rao, 2000). With the introduction of Se. sesban for soil fertility improvement in the tobacco-growing areas of southern Africa, the root-knot nematode problem became serious (Karachi, 1995; Shirima et al., 2000). In Tanzania, Meloidogyne infection was consistently highest when tobacco was planted after 2 years Se. sesban fallows compared with the crop in rotation with natural fallow (Shirima et al., 2000). In a study conducted in western Kenya, Meloidogyne infestation caused 52\%-87\% yield reduction in beans (Phaseolus vulgaris) planted after Se. sesban (Desaeger and Rao, 2000). A Crotalaria agatiflora cover-crop increased root-lesion nematode (Pratylenchus zeae) populations to levels that could limit maize growth, whereas it decreased Meloidogyne incognita and Mel. javanica populations during the same time (Desaeger and Rao, 2000). In another study (Desaeger and Rao, 2001), bean crop that followed mixed-species fallows of Se. sesban $+T e$. vogelii had increased root-knot nematode damage compared with bean grown after pure fallows of the respective species. On the contrary, bean crops that followed Se. sesban + Crotalaria grahamiana and $T e$. vogelii $+C r$. grahamiana did not experience yield losses. In a separate study conducted in the same area in western Kenya (Kandji et al., 2003), beans grew poorly when planted after Te. vogelii and Cr. grahamiana because of high incidence of Meloidogyne spp. in the first cropping cycle. In the second and third cropping seasons, while the population of Meloidogyne spp. decreased, spiral nematode (Scutellonema spp.) populations increased, which caused heavy losses of beans and maize planted after the legume fallows (Kandji et al., 2003). Studies by Kandji and coworkers (2001) found a positive correlation of Scutellonema populations with exchangeable bases in the soil. Pratylenchus populations were positively correlated with bulk density, whereas Meloidogyne populations were correlated with clay, potassium, and organic carbon content of the soil. On the other hand, Paratrichordorus and Xiphinema populations were correlated with calcium and soil bulk density (Kandji et al., 2001).

Rotational fallows also have significant effects on the incidence of insect pests of crop plants. According to Rao et al. (2000), chaffer grubs, which destroy maize seedlings, increased in maize planted after Se. sesban fallows in Kenya. Snout beetles (Diaecoderus sp.) that breed on Se. sesban, pigeon pea, Cr. grahamiana, and Te. vogelii during the fallow phase attacked maize planted after fallows with these plant species in eastern Zambia (Sileshi and Mafongoya, 2003). In an experiment involving pure fallows and mixtures of these legume species, the density of snout beetles was significantly higher in maize planted after Se. sesban $+\mathrm{Cr}$. grahamiana compared with maize planted after natural grass fallow. The population of beetles was significantly positively correlated with the amount of nitrate and total inorganic nitrogen content of the soil and cumulative litter fall under fallow species (Sileshi and Mafongoya, 2003). Beside Se. sesban being an alternative host of the beetle (Sileshi et al., 2000), its mixture with other legumes appeared to offer a favorable environment for the survival of the beetles during the fallow phase.

In the same study in eastern Zambia, Sileshi and Mafongoya (2003) recorded lower termite damage (\% lodged plants) on maize planted after Te. vogelii + pigeon pea, Se. sesban + pigeon pea, and pure Se. sesban than maize grown after natural fallow. Monoculture maize grown after the natural fallow had about 11 and 5 times more termite damage compared with maize grown after 
$T e$. vogelii + pigeon pea and Se. sesban + pigeon pea, respectively. The higher termite damage recorded in the natural fallow was apparently due to stress caused by weed competition. In another study conducted at four sites in eastern Zambia, Sileshi and coworkers (2005) found no difference between treatments in termite damage on maize plants after Te. vogelii, Tephrosia candida, Se. sesban, and Crotalaria pawlonia, a traditional grass fallow, monoculture maize grown with and without fertilizer. Though the differences were not statistically significant, maize planted after $T e$. candida fallows had consistently lower termite damage than fully fertilized monoculture maize at three out of the four sites. In western Kenya, incidence and damage due to groundnut hopper (Hilda patruelis) increased on farms where Cr. grahamiana was planted as a rotational fallow compared with new sites (Girma, 2002). The abundance of natural enemies and tri-trophic interactions in rotational woodlots and improved fallows has not been studied. Rotational systems at the landscape level may create a mosaic of fallowed and cropped plots and how such a situation affects pests needs to be evaluated.

\subsubsection{Simultaneous Agroforestry Practices}

\subsubsection{Trees on Cropland}

Rao et al. (1998) recognized three distinct categories of trees on cropland - scattered trees, boundary planting, and intercropping of annual crops between widely spaced rows of trees. Scattered trees in cropland, often known as "parklands" are widespread traditional practices in the semiarid tropics. The best known ones are those involving Faidherbia (Acacia) albida, Parkia biglobosa, Vitellaria paradoxa, Azadirachta indica in West Africa, and mango, Melia volkensii, Adansonia digitata, Parinari curatellifolia, Acacia spp. in the semiarid parts of eastern and southern Africa. Trees in these systems are rarely planted but are derived from natural regeneration and are protected by farmers. In such a setup, a pest may be shared between the tree and the associated crop or the adjacent vegetation and the resultant interactions may assume considerable significance. For instance, fruit flies (Ceratitis spp.) and false codling moth (Cryptophlebia leucotreta) are one such group of pests with a wide host range (De Meyer, 1998). The marula fly (Ceratitis cosyra) and false codling moths attack fruits of Uapaca kirkiana and Pari. curatellifolia as well as commercial fruits including mango, guava, avocado, peach, and citrus (Sileshi, unpublished data).

Trees in boundary planting and intercropping systems are deliberately planted and managed. Boundary planting involves trees on farm and field boundaries, soil conservation structures, and terrace risers. Intercropping systems use widely spaced rows of fast-growing trees such as Cedrela odorata, Se. sesban, and Grevillea robusta in banana and bean fields. The management of trees used as windbreaks around orchards and surrounding trees and bushes has also a significant effect on the populations of pest organisms and natural enemies. The effect of trees on cropland on pests has been reviewed by Rao et al. (2000) and Schroth et al. (2000). However, systematic studies investigating the effect of trees on cropland on tri-trophic interactions are virtually lacking.

\subsubsection{Mixed Intercropping}

Mixed intercropping involves relay intercropping and coppicing legume fallows. In the context of using leguminous trees for soil fertility replenishment, relay intercropping has been found to be more appropriate than rotational fallows in areas characterized by high population density and land scarcity, where farmers cannot forego crops for the tree-fallow phase. A typical situation is that of southern Malawi where trees or shrubs such as pigeon pea, Tephrosia spp., and Se. sesban are planted between rows or within the rows of an already established maize crop (Phiri et al., 1999).

Coppicing tree fallows are another variant of mixed intercropping combining the elements of rotational fallow (the fallow phase) and intercropping (the resprouting phase) (Sileshi and Mafongoya, 2006). Tree species that resprout when cut at fallow termination are called coppicing species. The legume species used in coppicing fallows include Acacia spp., Gliricidia sepium, Leucaena 
spp., Calliandra calothyrsus, Senna siamea, and Flemingia macrophylla. Pure stands of these species are normally planted at a spacing of $1 \times 1 \mathrm{~m}$ and the fallows are left to grow for 2-3 years. At the end of the fallows, the trees are cut, and the leaves and twigs are incorporated into the soil with a hand hoe. Every time the stumps resprout, the coppice biomass is cut and incorporated into the soil. A cereal crop, often maize, is planted on the ridges between the tree stumps.

Like the short-duration fallow species, legumes grown in mixed intercropping have a significant impact on witch weeds. The incidence of St. asiatica was monitored (Sileshi et al., 2006) in 1995-1997 cropping seasons in coppicing fallows established in 1991 and 1992 at Msekera in eastern Zambia. The density of St. asiatica weeds was lower in maize grown in the coppicing fallows of $S$. siamea, Flemingia congesta, and L. leucocephala than in monoculture maize, whereas maize grown in those of Ca. calothyrsus and $G$. sepium did not differ from monoculture maize.

Legume trees grown in mixed intercropping can also influence insect pest populations. In a study in Malawi, Sileshi et al. (2000) found higher densities of the bean beetle (Ootheca benningseni) in farms where Se. sesban was relay cropped with legumes such as cow pea (Vigna unguiculata), bean, soybean (Glycine max), and bambara groundnut (Vigna subterranea). In another study in Zambia, the beetle density and damage was higher in farms where Se. sesban was planted next to cowpea and Hyacinth bean (Dolichos lablab). The beetle caused $100 \%$ defoliation of both Se. sesban and the other legumes (Sileshi et al., 2000).

Sileshi and coworkers (2005) monitored termite damage on maize for 2 years in an experiment established in 1992 (described earlier) and a second experiment established in 1997 at Msekera. In the experiment established in 1992, maize grown in the traditional fallow and $S$. siamea had significantly higher percentage of lodged plants than fully fertilized monoculture maize during the 2001-2002 cropping season. The damage to maize grown in Ca. calothyrsus, G. sepium, and $F l$. macrophylla did not differ from that in monoculture maize. On the contrary, during the 2002-2003 cropping season, fully fertilized monoculture maize had significantly more damaged plants than maize grown in the different fallows except $F l$. macrophylla. In this experiment, total inorganic nitrogen, soil water at planting, and coppice biomass applied during the season accounted for $59 \%$ of the variance in the percentage of lodged maize plants. In the experiment established in 1997, the percentage of lodged plants was significantly higher in fully fertilized monoculture maize grown continuously without fertilizer than in maize grown in Ac. anguistissima fallows in the 20012002 cropping season, whereas in the 2002-2003 cropping season, no difference was noted among treatments. The percentage of lodged maize plants was significantly correlated with preseason inorganic nitrogen (Sileshi et al., 2005). Hardly any study investigated the effect of mixed intercropping on natural enemies.

\subsubsection{Alley Cropping}

Alley cropping (also called hedgerow intercropping) involves continuous cultivation of annual crops within hedgerows formed by leguminous trees and shrubs. The legumes are periodically pruned and their biomass is applied either as mulch or incorporated into the soil to improve soil fertility (Kang, 1993).

Trees in alley-cropping arrangements can have significant effects on the incidence of weeds, diseases, and insect pests. Studies in Kenya (Jama et al., 1991; Jama and Getahun, 1992) showed $42 \%-98 \%$ reduction in weed biomass in maize and green gram (Phaseolus aureus) alley cropped with F. (Acacia) albida and L. leucocephala compared with the respective monocrops. In Costa Rica, Rippin et al. (1994) reported a 52\% and 28\% reduction in weed biomass in maize grown between Erythrina poeppigiana and G. sepium hedgerows, respectively. One of the most important aspects of alley cropping is control of problematic weeds such as speargrass (Imperata cylindrical) (Garrity, 1997). On Alfisols in Nigeria, hedgerows of L. leucocephala and G. sepium reduced the population of speargrass by $51 \%-67 \%$, aboveground biomass by $78 \%-81 \%$, and belowground 
rhizomes by $90 \%-96 \%$ compared with a speargrass bush fallow (Anoka et al., 1991). Similarly, on Ultisols in Indonesia, hedgerows of G. sepium reduced speargrass infestation (ICRAF, 1996). However, hedgerow species show striking differences in their ability to control weeds. For instance, G. sepium was better than L. leucocephala in suppressing speargrass on tropical Alfisols in Nigeria (Anoka et al., 1991). On the contrary, Yamoah et al. (1986) reported that S. siamea controlled weeds better than G. sepium and Fl. macrophylla in Nigeria. In Peru, Inga achieved greater weed control than Leucaena or Erythrina (Salazar et al., 1993). These differences have been suggested to be due to differences in canopy spread among hedgerow species, the amount of biomass they produce, and the decomposition rate of the biomass (Rao et al., 1998).

Alley cropping may affect the development of crop diseases positively or negatively. Studies by Yamoah and Burleigh (1990) in Rwanda suggested that alley cropping with Se. sesban slowed down the development of maize rust (Puccinia sorghi). The proportion of infected leaves per plant, number of uredinia per plant, and area under disease progress curve in monocrop maize were significantly greater than in alley-cropped maize. Rust development on maize in middle rows was also significantly greater than that in the rows bordering Se. sesban hedges (Yamoah and Burleigh, 1990). In Côte d'Ivoire, G. sepium hedgerows reduced severe virus infestation and incidence of late leaf spot (Phaeoisariopsis personata) and rust (Puccinia arachidis) of alley-cropped groundnut (Schroth et al., 1995a). Mulch with G. sepium foliage also reduced the incidence of late leaf spot and rust when applied to a monocrop groundnut. In Kenya, however, the incidence and severity of angular leaf spot (Phaeoisariopsis griseolal) and anthracnose (Colletotrichum lindemuthianum) on beans were higher in L. leucocephala alleys than in monocropped beans (Koech and Whitbread, 2000). The incidence and severity of both these diseases increased as the alley width decreased from 8 to $2 \mathrm{~m}$. The disease incidence in this study was related to microclimate change, whereas in the previous study a suppressive effect of tree mulch on groundnut diseases was the cause. However, Schroth et al. (1995a) found an increase in groundnut disease in those parts of alleys that were the most shaded by trees. In Philippines, the incidence of blast (Pyricularia oryzae) and its damage on rice was higher in alley cropping than in a monocropped control (Maclean et al., 1992).

Hedgerows of trees were reported to affect pests of different alley crops differently. In a study that evaluated the effects of alley cropping on the abundance of insect pests of beans and maize in semiarid Kenya, Girma et al. (2000) recorded higher bean fly (Ophiomyia spp.) infestation on beans in the presence of G. sepium, Gre. robusta, S. siamea, Senna spectabilis, Fl. congesta, Croton megalocarpus, Morus alba, C. calothyrsus, and Lantana camara hedgerows than in their absence. In contrast, maize in the hedgerows experienced significantly lower stalk borer (Busseola fusca and Chilo spp.) and aphid (Rhophalosiphum maidis) infestations than monocrop maize. Aphid (Aphis fabae) infestation of beans, however, did not differ between treatments (Girma et al., 2000). In another study conducted at two sites in Kenya (Mtwapa and Amoyo), the abundance of adult, larval, and pupal stages of stem borers, defoliation, stem damage, and plant mortality due to maize stem borers (Chilo partellus, Ch. orichalcociliellus and Sesamia calamistis) was significantly lower in L. leucocephala alley cropping than in a maize monocrop (Ogol et al., 1999). There were also significantly fewer stem borer eggs in unweeded maize-Leucaena alley cropping than in the weeded plots.

Not only do trees in alley cropping affect weeds, diseases, and insect pest, but also vertebrate pests. In Nigeria, it was difficult to establish annual crops such as maize closer to L. leucocephala and G. sepium trees than away from them because of increased damage to seedlings by birds and rodents. In Côte d'Ivoire, rodents also fed preferentially on maize and groundnut seeds sown close to the hedgerows. At harvest, the number of plants in the first crop row from the trees was reduced by $25 \%$ and $20 \%$ for maize and groundnut, respectively (Schroth et al., 1995b). In Côte d'Ivoire and elsewhere, birds and mice hiding in the foliage of the G. sepium hedgerows were observed to feed on the maturing rice grains (Schroth et al., 1995b).

The effect of trees on natural enemies and tri-trophic interactions has been studied more systematically in alley cropping than the agroforestry practices discussed earlier. In the study by 
Girma et al. (2000), the population of ladybird beetles closely followed their prey (aphids). Activity of wasps was significantly greater close to hedgerows than away from them. Spider abundance during the maize season was $77 \%$ greater in the presence of hedgerows than in their absence, but catches during other seasons were similar between the two cropping systems. In an experiment conducted at two sites (Mtwapa and Amoyo) in Kenya, mean rates of parasitism on maize stem borer eggs, larvae, and pupae were not affected by alley cropping of maize with L. leucocephala at Mtwapa, whereas parasitism was significantly higher in maize monocrop than in alley cropping at Amoyo (Ogol et al., 1998). Predation of stem borer eggs was significantly higher in monocrop maize than in alley-cropping plots. There were no differences in predation between unweeded alley cropping and clear weeded plots.

\subsubsection{Multistrata Agroforestry Systems}

Multi-strata agroforestry systems with tree crops comprise a variety of land use systems ranging from plantations of commercial crops under shade trees to highly diversified multistory tree-based homegardens. Multistrata agroforestry systems may also include plantations of such crops as coffee (Coffea spp.), cacao (Theobroma cacao), or tea (Camellia sinensis) with various shade tree species (Beer et al., 1998). In many of these systems, coffee and cocoa are grown under a canopy of shade trees that may be remnants of the original forest or have been deliberately planted.

Tropical homegardens are the most complex of the multi-strata agroforestry practices (Fernandes and Nair, 1986). In the homegardens, intensive mixed intercropping is practiced throughout the year. This involves the integration of several trees with food, cash crops, and livestock simultaneously on the same unit of land. On an average-sized farm (0.2-1.2 ha) over a hundred different plant species can be found, making this system highly integrated. The spatial arrangement of components is irregular and appears very haphazard with trees or shrubs and food crops intimately mixed. Vertically, however, 2-4 relatively distinct canopy layers can be recognized (Fernandes and Nair, 1986).

Whether a particular interaction in multi-strata systems is detrimental or beneficial in terms of pest and disease incidence is largely dependent on complex factors, including management practices, the pest species, the climate, soil, and so on. Correct pruning and avoidance of heavy shade can provide some control of the many coffee diseases such as coffee berry disease (CBD), or insect pests such as Antestia bugs (Antestisopsis spp.), which are common pests of Arabica coffee throughout sub-Saharan Africa. Anthestia lineaticollis caused less damage where coffee is properly shaded, whereas capsid bugs (Lycidocoris mimeticus) and the coffee berry borer (Hypotenemus hampei) populations are favored by dense shade in coffee (Beer et al., 1998). In the Brazilian Amazon, rice, bean, and maize experienced higher pest infestations when these crops were intercropped with trees than in their respective pure crops. According to Fazolin and Estrela (1999), pest infestations depended on the tree species. A detailed overview of shade effects on crop pests is provided by Schroth et al. (2000).

Several studies have shown that trees in multi-strata agroforestry can influence the abundance of natural enemies. Moderate shade favored the parasitic wasp Cephalonomia stephanoideri and the entomopathogenic fungus Beauveria bassiana, which control the coffee berry borer (Beer et al., 1998). Coconut planted in cocoa provided nest sites for the predatory ants Dolichoderus and Oecophylla, which reduced Helopeltis damage to cocoa (Way and Khoo, 1999). Klein et al. (2002) found an increased predator-prey ratio in more diverse traditional agroforestry systems compared with intensified systems in Indonesia. In the Guatemalan farms, Greenberg et al. (1997b) found a 30\% increase in bird abundance and 15\% more species in shaded than sun coffee plantations. Greenberg et al. (1997a) found even greater increases in these values in Mexico, where shade tree canopies were more structurally and floristically diverse and less well pruned. Birds reduced the abundance of large arthropods by at least 64\%-80\% (Greenberg et al., 2000). 


\subsection{ECOLOGICAL HYPOTHESES REGARDING INTERACTIONS}

From the review in the earlier section it is clear that tree-crop associations can increase, reduce, or have no effect on pest loads in agroforestry systems. This agrees with studies on mixtures of annual crops, especially intercrops (Risch et al., 1983). This shows that the response of herbivores to vegetation diversity is highly dependent on both host plant and pest species as well as management regimes (Table 5.1). An understanding of the causes for reduction in pest load in intercrops has received considerable attention. The pattern of pest incidence in agroforestry practices apparently results from a variety of causes (Table 5.1, Figure 5.1), and some of these do not have parallels in annual intercrops. In the course of this chapter, we noted that most of the studies focused on attempting to detect differences between a monoculture and an agroforestry system, which are two unrelated land use practices. In most of the studies where differences were reported, no further attempts were made to identify the underlying mechanisms that led to such differences. We found few cases (Ogol et al., 1998, 1999; Koech and Whitbread, 2000; Rao et al., 2000) where attempts were made to relate the biophysical changes that result from tree-crop interactions and their effects on pests in relation to ecological hypotheses.

Recent agroforestry literature has placed considerable emphasis on the effect of plant diversity on agroforestry pest management (Vandermeer and Perfecto, 1998; Rao et al., 2000; Schroth et al., 2000 ) with the optimism that structural heterogeneity and genetic diversity in agroecosystems regulate pest populations. However, the question remains as to how much diversity of plant species is required to achieve the desired pest control. There are several hypotheses describing the possible roles of increasing biodiversity in ecosystem function (Lawton, 1994), and each hypothesis can be illustrated by showing the effect of increasing species richness on the rate of an ecosystem process such as decomposition, predation, parasitism, and so on.

First, the redundant species hypothesis suggests that ecosystem processes benefit from an increase in biodiversity up to a threshold level beyond which there is no influence of further increase in species diversity. In contrast, the rivet hypothesis suggests that each species plays a significant role in affecting the ecosystem process; even a small decrease in diversity will result in a decrease in the rate of an ecosystem process. According to this hypothesis, various forms of the function between the ecosystem process and diversity are possible, but all assume that each species has a unique contribution to that process. Third, the idiosyncratic response hypothesis suggests that increasing biodiversity affects ecosystem functions in an unpredictable way because of the complex and varied roles of individual species. Finally, the null hypothesis is that ecosystem function is insensitive to species deletion or addition (Lawton, 1994).

The plant species diversity in agroforestry systems ranges from as few as two to over 100 species, and rules on the effect of diversity on pests and natural enemies, if they exist, are unlikely to apply in the same way to all systems. The experimental data available from simpler studies comparing single- and two-species mixtures show variability in the responses of individual pests. For instance, Se. sesban $+T e$. vogelii increased root-knot nematodes on bean in Kenya (Desaeger and Rao, 2001), whereas the same treatment increased the incidence of snout beetles on maize in Zambia (Sileshi and Mafongoya, 2003). Similarly, while Se sesban $+\mathrm{Cr}$. grahamiana reduced root-knot nematodes in bean in Kenya (Desaeger and Rao, 2001), the same treatment increased snout beetle incidence on maize in Zambia (Sileshi and Mafongoya, 2003) compared with pure fallows of the respective species. Although multi-strata agroforests are regarded as the most diverse of all agroecosystems, the number of clearly documented cases of reduction in pest damage or increase in natural enemies is limited. There is also clear lack of experimental data to support any of the hypotheses mentioned earlier. In the following discussion, we examine the implications of tree-crop interactions on pests in the light of six other ecological hypotheses. 


\subsubsection{Plant Stress Hypothesis}

According to the plant stress hypothesis (White, 1984), plants that are under physiological stress represent higher quality of food for insect herbivores than those growing under optimal conditions and are likely to be more prone to pest attacks. The mechanism underlying this hypothesis is that some plants respond to stress with increases in soluble nitrogen and free amino acids in their tissues. However, not all plants respond to stress in this way, and other mechanisms have been suggested. Stress-induced changes in leaf size, leaf toughness, plant architecture, resin production, and plant physiology have also been associated with increased susceptibility to insect attack. Although water deficit is a common cause of stress in plants, factors such as browsing and excessive exposure to sun, hail damage, damage by other insects, root disturbance, and nutrient deficiency can all alter the susceptibility to insect herbivores (Speight et al., 1999; Gebeyehu and Wingfield, 2003). Droughtinduced stress has been one of the well-documented cases inducing insect pest outbreaks (Mattson and Haack, 1987). Termites often attack plants stressed by drought (Logan et al., 1990). The pine weevil Pis. nemorensis has been associated with trees that are stressed by hail damage and poor species-site matching (Gebeyehu and Wingfield, 2003). Stress may also be induced by damage due to insects, nematodes, plant pathogens, or weed competition. Plants damaged by one type of herbivore may also be more suitable for another. For instance, pine trees damaged by the wood wasp (Sirex noctilio) provide attractive breeding material for the weevil Pis. nemorensis (Gebeyehu and Wingfield, 2003). Another wood wasp (Sirex giga) depends on the fungus Amylosteruem spp., and acts as its vector from one pine tree to another to breakdown the host's heartwood so that its larvae can develop on the stressed host. Even routine management practices can induce stress and promote pest attack. For instance, in Kenya, pruning of $S$. siamea invoked a significant increase in attack by stem-boring larvae (Opondo-Mbai, 1995), with a resultant decline and eventual death of the plants.

In simultaneous agroforestry systems, competition between trees and crops for limited resources could increase their stress level. In semiarid environments, competition for water and nutrients dominates tree-crop interactions (Rao et al., 1998), which may affect the growth and susceptibility of crops to insects. Poor-quality tree litter in the course of decomposition may immobilize nutrients, especially nitrogen, in the soil (Mafongoya et al., 1998), and this may increase damage by insects. For example, nitrogen levels in the soil influence the level of termite damage on maize (Sileshi et al., 2005). Greater termite attack due to water stress is another major cause for high mortality of maize and tree seedlings. Agroforestry species may reduce stress indirectly by their ability to reduce weed infestation. Sileshi and Mafongoya (2003) demonstrated that termite damage on maize grown after agroforestry was lower compared with those after a natural fallow due mainly to reduction in stress caused by weed competition in the agroforestry plots. Some tree species used in agroforestry are also known to inhibit crop growth underneath their canopies due to allelopathic effects of root exudates and or litter decomposition products (Bhatt et al., 1997). The plant stress hypothesis has been a subject of considerable controversy (Speight et al., 1999).

\subsubsection{Plant Vigor Hypothesis}

The plant vigor hypothesis (Price, 1991) contends that insect herbivores perform better on vigorous, not stressed plants. The plant vigor hypothesis has been supported by several cases of insect-plant associations (Speight et al., 1999). Despite the prominence of soil fertility studies in agroforestry research, there is little mention in the literature of agroforestry effects on crop health via nutrient availability. Improved soil structure and root development, and biological nitrogen fixation by legume trees significantly improve crop nutrition. On nutrient-deficient sites, the additional nitrogen, phosphorus, and potassium supply from leguminous biomass may markedly improve crop vigor (Schroth et al., 2000). For instance, in alley cropping, coppicing fallows and systems with perennial crops and leguminous shade trees, large quantities of nitrogen-rich biomass may be 
applied to the crops. Studies show that nitrogen is the major determinant of insect community structure (West, 1985; Speight et al., 1999). The plant vigor hypothesis points to the valid concern that nitrogen may reduce crop resistance against insects and diseases when supplied in excess.

\subsubsection{Carbon-Nutrient Balance Hypothesis}

According to this hypothesis, carbon-rich defensive compounds such as tannins and terpens should occur in greater concentrations in low-nutrient or high-light environments (Bryant et al., 1983). Individual plants growing under low-nutrient conditions have high carbon/nutrient ratios. Carbonrich secondary metabolites act as sinks for excess carbon, and pathways that generate carbon-rich defenses are favored. Under high-nutrient conditions, however, carbon-nutrient ratios are lower, and pathways associated with growth and reproduction are favored over defense. Nitrogen availability is easiest to increase through agroforestry measures, and its increased supply from nitrogen-rich biomass may increase crop susceptibility. This has been demonstrated in a rice-blast pathosystem in alley cropping (Maclean et al., 1992). High nitrogen supply is also known to increase the infestation of obligate parasites such as rust fungi (Puccinia spp.). In addition to nitrogen, potassium is another nutrient through which agroforestry practices are most likely to affect crop health. A high potassium supply generally improves the resistance of plants to fungi, bacteria (Marschner, 1995), and nematodes up to the level required for optimum plant growth. However, woody biomass may contain high concentrations of potassium, which becomes readily available on decomposition. Mulching with prunings from legume trees in alley cropping has also been found to improve the potassium nutrition of maize (Schroth et al., 1995b). High nitrogen and potassium supply favors attack of field crops by insect pests, mainly because of the increased content of amino acids in the plant (Marschner, 1995). This points out to the fact that, in addition to increasing plant vigor, the high nutrient availability in agroforestry could reduce carbon-nutrient ratios and hence the plant's defense system. The carbon-nutrient balance hypothesis has provided a framework for much valuable research on environmental-based variation in plant defense, yet it remains controversial. Nonetheless, a significant number of studies support, at least partially, this hypothesis (Speight et al., 1999).

\subsubsection{Natural Enemies Hypothesis}

The natural enemies hypothesis posits that vegetation diversity increases both population size and impact of predators and parasitoids that regulate herbivorous arthropod pests (Root, 1973). Many studies of polyculture systems have supported the natural enemies hypothesis, whereas others have reported neutral or even negative responses (Letourneau, 1987; Ogol et al., 1998). Only few studies have assessed the effect of agroforestry practices on interactions in relation to the natural enemies hypothesis.

Ogol et al. (1998) evaluated the natural enemies hypothesis in a maize-L. leucocephala hedgerow intercropping at two sites in Kenya. In this study, the rates of egg, larval, and pupal parasitism of maize stem bores contradicted the natural enemies hypothesis at one site, whereas parasitism showed a neutral response to plant diversity at the other site. In the same study, egg predation rates contradicted the natural enemies hypothesis, whereas pathogen-associated mortality of stem borer larvae exhibited a neutral response to plant diversity (Ogol et al., 1998). The examples above indicate that the notion that vegetation diversity in agroforestry increases abundance of natural enemies is clearly not tenable. In fact, there is no rule of thumb or general theory that globally predicts population size or activity of natural enemies in diverse agroecosystems, and thus each system must be evaluated individually.

\subsubsection{Resource Concentration Hypothesis}

The resource concentration hypothesis (Root, 1973), also called disruptive-crop hypothesis (Vandermeer, 1989), may operate when a pest (1) is less likely to find its host plant because of 
some kind of chemical or physical confusion imposed by a second species and (2) after finding a host plant, it is more likely to leave that patch because of the presence of nonhost plants. The disruptive species may also exert its influence indirectly by creating an unfavorable microclimate for the pest, or by affecting the quality of the host plants making them less desirable to the pest compared with individuals in monoculture. The resource concentration hypothesis is largely applicable to specialist herbivores (Vandermeer, 1989). However, it is equally applicable to the incidence of diseases.

Trees being the taller component in agroforestry may act as physical barriers to the dispersal and colonization of a crop by both herbivores and natural enemies or have a biological role in repelling pests because of their unfavorable morphological features. Upper story trees may camouflage the understory host crops and prevent pests from recognizing them from a distance. In such systems, herbivores such as aphids are more likely to be affected because of their relatively poor efficiency in locating their host plants and their inability to survive for long without feeding. As the number of plant species increases, the number of aphid species is also known to decrease (Dixon et al., 1987).

Ogol and coworkers (1998) provide a direct support for this hypothesis from a maizeL. leucocephala alley-cropping study in Kenya. In their study, colonization by maize stem borers (Chilo spp.), which are relatively specialist herbivores, was lower in alley cropping compared with a monocrop maize. Host location was probably affected by the presence of both Leucaena and weeds, which reduced the borers' ability to locate their hosts. The weeds and hedges also acted as a mechanical barrier to the dispersal of the young larvae of maize stalk borers. This is evidenced by Chilo egg batches deposited on weeds (Ogol et al., 1998).

Like the other hypotheses, the resource concentration hypothesis has been a subject of considerable controversy, and may not adequately explain some of the population variations. For instance, Rhainds and English-Loeb (2003) experimentally manipulated attributes of patches with strawberry plants to assess the impact of patch size and host density on the abundance of tarnished plant bug and fruit damage. The density of nymphs increased with patch size and host density for some but not all generations of plant bug, providing partial support for the resource concentration hypothesis. The validity of the resource concentration hypothesis needs to be tested in the more species-rich tropical homegardens.

\subsubsection{Microclimate Hypothesis}

The microclimate hypothesis (Koech and Whitbread, 2000) is based on the observation that agroforestry practices affect the microclimate around the crop. The microclimate changes caused by trees in tree-crop associations include shading of the understory crops, increased relative humidity, reduced air and soil temperatures, and decreased wind speed (Schroth et al., 1995a; Koech and Whitbread, 2000). The canopy cover also affects the microclimate of the under story (Perfecto and Vandermeer, 1996). These changes may have negative, positive, or neutral impacts on weeds, pathogens, insect, and their natural enemies (Sileshi, 1997). For instance, the complementary effect of shading in the alleys, mulch from prunings, and potential allelopathy from hedgerow species reduce weed populations in alley cropping (Kang, 1993; Rao et al., 1998). Shading by G. sepium and L. leucocephala caused $31 \%$ and $25 \%$ rhizome mortality in speargrass, respectively (Anoka et al., 1991). Hedgerow shading and mulch may lead to shifts over time in the composition of weed species (Anoka et al., 1991; Ong and Rao, 2001). In Nigeria, G. sepium and L. leucocephala caused a shift from speargrass to other weeds such as Rottboellia, Hippocratea, Chromolaena, Talinum, and Euclasta (Anoka et al., 1991).

Changes in light, temperature, and relative humidity and leaf wetness have been cited as causes for increased incidence and severity of anthracnose and angular leaf spot on beans in rows adjacent to L. leucocephala hedges (Koech and Whitbread, 2000), and leaf spot and rust on groundnut in G. sepium alley cropping (Schroth et al., 1995a). Similarly, increased populations of Cicadulina sp., which is the vector of maize streak virus, under trees in Burkina Faso was due to the change in 
microclimate (Traoré and Quedraogo, 1997). Similarly, the shading due to the canopy appears to be a major factor influencing the arthropod community in shade-coffee (Perfecto and Vandermeer 1996; Greenberg et al., 2000).

\subsection{SUMMARY AND CONCLUSIONS}

Tropical agroforestry practices range from the short-duration improved fallows where a single legume tree or shrub species is rotated with a crop to the most diverse multi-strata homegardens. In simultaneous systems such as alley cropping and coppicing fallows, the contrasts between the component species in their physical dimensions, their life span, and their physiological responses may lead to complex interactions between the tree and the crop species. Therefore, the tri-trophic interactions occurring here are expected to be more complex than those in sequential tree-crop fallow systems. The arrangement and the management of trees in relation to crops within an agroforestry technology has a bearing on microclimatic factors. Both bottom-up effects of the abiotic environment and top-down effects of herbivores and their natural enemies can modify pest incidence in the system. Pest problems may increase in some systems that either induce stress (plant stress hypothesis) or improve crop vigor (crop vigor hypothesis and carbon-nutrient balance hypothesis).

None of the proposed hypotheses really explain all the possible mechanisms by which pest risks will increase or decrease in agroforestry. It is well to remember that all of the hypotheses have been convincingly demonstrated in one system or another, and it is not a question of one being generally right and the other wrong. Some degree of advocacy seems to have also evolved concerning them (Vandermeer, 1989; Speight et al., 1999). However, this does not necessarily mean that they are adequate to explain those mechanisms that reduce or increase pest load in all systems. For instance, where trees are dispersed in cropland, the influence of trees on pests is probably limited to the crop under the tree canopy (Rao et al., 2000). In alley cropping or boundary planting, the interaction between trees and crops is mostly confined to the tree-crop interface, so trees are unlikely to influence pests on crop plants several meters away from them as indicated by the various examples (Yamoah and Burleigh, 1990; Jama et al., 1991; Koech and Whitbread, 2000). This calls for reexamination of the various hypotheses in the different systems.

In some cases, joint operation of two hypotheses is a clear possibility. It must also be borne in mind that it is difficult to reconcile some of the hypothesis, for instance, the plant stress hypothesis and the plant vigor hypothesis, into a single theory to explain patterns of insect attack. Some of the contradictions arise from the fact that there are many different kinds of stress, many idiosyncratic responses by plants, and equally diverse responses by insects. The biggest challenge now is to understand these idiosyncrasies and apply them to design of agroforestry systems. If agroforestry is to thrive well as an applied ecological science offering strategies for sustainable utilization of natural resources, pest management should be based on applying ecological principles and practical decision-making tools.

The extent of pest damage in any of the systems may be determined by the interactions (1) between the plant community and the herbivore or pathogen, (2) between the herbivores and their natural enemies, and (3) among components (tree, crop, soil, and environment) of the system. The consequences of these interactions may have a positive, negative, or neutral effect on pests. An understanding of these interactive effects on pests and their natural enemies at different spatial and temporal scales is essential. This will help in designing more robust agroforestry practices that lower pest problems. It is an ecological maxim that diversity is closely related to stability (Risch et al., 1983). However, simply increasing diversity will not necessarily increase the stability of all ecosystems. Ewel (1999) pointed out from the experience of his constructed mimics that diversity cannot be counted on to afford protection from herbivores, and some times can have the opposite effect. For employing plant diversity strategically in agroforestry design, more is required than simply adding more plant species to a species-poor system. As argued by Ewel (1999), any addition 
of species into existing systems must also be based on recognition of the existing biophysical conditions and less so on the structural and functional dynamics of ideal native vegetation or manmade models. In short, design of innovative agroforestry practices that reduce pest management should be based on ecological principles.

\section{ACKNOWLEDGMENTS}

Financial support for the senior author was obtained from the Canadian International Development Agency (CIDA) and Swedish International Development Cooperation (SIDA) through the Zambezi Basin Agroforestry Project.

\section{REFERENCES}

Agrios, G.N. 1988. Plant Pathology. New York: Academic Press.

Akobundu, I.O. and F. Ekeleme. 2002. Weed seedbank characteristics of arable fields under different fallow management systems in the humid tropical zone of southeastern Nigeria. Agroforestry Systems 54:161-170.

Annon. 1997. Lifting the curse of Striga. In Integrated Pest Management at the International Agricultural Research Centres, 13. The CGIAR System-Wide Programme on Integrated Pest Management. Davis, CA: The Printer.

Anoka, U.A., I.O. Akobundu and S.N.C. Okonkwo. 1991. Effect of Gliricidia sepium (Jacq.) Steud. and Leucaena leucocephala (Lam.) de Wit on the development of Imperata cylindrical (L.) Raeuschel. Agroforestry Systems 16:1-12.

Beer, J., R. Muschler, D. Kass and E. Somarriba. 1998. Shade management in coffee and cacao plantations. Agroforestry Systems 38:139-164.

Bhatt, B.P., M.S. Kaletha and N.P. Todaria. 1997. Allelopathic exclusion of multistorey crops by agroforestry trees of Garhwal Himalayas. Allelopathy Journal 4:321-328.

Bryant, J.P., F.S. Chapin and D.R. Klein. 1983. Carbon/nutrient balance of boreal plants in relation to vertebrate herbivory. Oikos 40:357-368.

Bugg, R.L. and C. Waddington. 1994. Using cover crops to manage arthropod pests of orchard: a review. Agriculture, Ecosystem and Environment 50:11-28.

Day, R. and S.T. Murphy. 1998. Pest management in tropical agroforestry: prevention rather than cure. Agroforestry Forum 9:11-14.

De Meyer, M. 1998. Revision of the subgenus Ceratitis (Ceratalaspis) Hancock (Diptera: Tephritidae). Bulletin of Entomological Research 88:257-290.

Desaeger, J. and M.R. Rao. 2000. Parasitic nematode populations in natural fallows and improved cover crops and their effects on subsequent crops in Kenya. Field Crops Research 65:41-56.

Desaeger, J. and M.R. Rao. 2001. The potential of mixed cover crops of Sesbania, Tephrosia and Crotalaria for minimizing nematode problems in subsequent crops. Field Crops Research 70:111-125.

Desaeger, J., M.R. Rao and J. Bridge. 2004. Nematodes and other soilborne pathogens in agroforestry. In Below-Ground Interactions in Tropical Agroecosystems: Concepts and Models with Multiple Plan Components, ed. M. van Noordwijk, G. Cadisch and C.K. Ong, 263-283. Wallingford: CABI Publishing.

Dix, M.E., R.J. Johnson, M.O. Harrell, R.M. Case, R.J. Wright, L. Hodges, J.R. Brandle, M.M. Schoeneberger, N.J. Sunderland, R.L. Fitzmaurice, L.J. Young and K.G. Hubbard. 1995. Influence of trees on abundance of natural enemies of insect pests: a review. Agroforestry Systems 29:303-311.

Dixon, A.F.G., P. Kindlmann, J. Leps and J. Holman. 1987. Why there are so few species of aphids, especially in the tropics. American Naturalist 129:580-592.

Duponnois, R., K. Senghor, J. Thioulouse and A.M. Bâ. 1999. Susceptibility of several Sahelian Acacia to Meloidogyne javanica (Treub) Chitw. Agroforestry Systems 46:123-130.

EPPO. 2006. Toxoptera citricidus. EPPO Bulletin 36:451-456. http://www.blackwell-synergy.com/doi/ pdf/10.1111/j.1365-2338.2006.01040.x 
Ewel, J.J. 1999. Natural systems as models for the design of sustainable systems of land use. Agroforestry Systems 45:1-21.

Fazolin, M. and J.L.V. Estrela. 1999. Population and levels of damage of the main pests of bean, corn and rice in an Agroforestry system in the Amazon region. In Multistrata Agroforestry Systems with Perennial Crops, ed. F. Gimenez and J. Beer, 107-111. Turialba, Costa Rica: CATIE.

Fernandes, E.C.M. and P.K.R. Nair. 1986. An evaluation of the structure and function of tropical homegardens. Agricultural Systems 21:279-310.

Gacheru, E. and M.R. Rao. 1998. Prospects of agroforestry for Striga management. Agroforestry Forum 9(2):22-27.

Gallagher, R.S., E.C.M. Fernandes and E.L. McCallie. 1999. Weed management through short-term improved fallows in tropical agroecosystems. Agroforestry Systems 47:197-221.

Garrity, D.P. (ed). 1997. Agroforestry innovations for Imperata grassland rehabilitation. Agroforestry Systems (Special Issue) 36:1-274.

Gathumbi, S.M. 2000. Nitrogen sourcing by fast-growing legumes in pure and mixed species fallows in western Kenya. Ph.D. thesis, Wye College, University of London, Wye, Kent, UK.

Gebeyehu, S. and M.J. Wingfield. 2003. Pine weevil Pissodes nemorensis: threat to South African pine plantations and options for control. South African Journal of Science 99:531-536.

Girma, H. 2002. Insect pest problems and their management in planted fallow crop rotation in western Kenya. $\mathrm{Ph} . \mathrm{D}$. thesis, Kenyatta University, Nairobi, Kenya.

Girma, H., M.R. Rao and S. Sithanantham. 2000. Insect pests and beneficial arthropods population under different hedgerow intercropping systems in semiarid Kenya. Agroforestry Systems 50:279-292.

Greenberg, R., P. Bichier and J. Sterling. 1997a. Bird populations in planted and rustic shade coffee plantations of Chiapas, Mexico. Biotropica 29:501-514.

Greenberg, R., P. Bichier, A. Cruz Angon and R. Reitsma. 1997b. Bird populations in shade and sun coffee plantations in Central Guatemala. Conservation Biology 11:448-459.

Greenberg, R., P. Bichier, A. Cruz Angon, C. MacVean, R. Perez and E. Cano. 2000. The impact of avian insectivory on arthropods and leaf damage in some Guatemalan coffee plantations. Ecology 81: $1750-1755$.

Hitimana, N. and R.G. McKinlay. 1998. The effect of intercropping on phytophagous pests: a review. Agroforestry Forum 9:9-11.

Huxley, P.A. and D.J. Greenland. 1989. Pest management in agroforestry systems: a record of discussions held at CABI, Wallingford, UK, 28-29 July 1988. Agroforestry Abstracts 2:37-46.

ICRAF. 1993. Annual report for 1992. Nairobi, Kenya: International Centre for Research in Agroforestry.

ICRAF. 1996. Annual report for 1995. Nairobi, Kenya: International Centre for Research in Agroforestry.

ISPM. 2006. Glossary of phytosanitary terms. International Standard for Phytosanitary Measures No. 5. Rome, Italy: FAO. http://www.eppo.org/QUARANTINE/ISPM_05_2006\%20Glossary.pdf

Jama, B. and A. Getahun. 1992. Intercropping Acacia albida with maize (Zea mays) and green gram (Phaseolus aureus) at Mtwapa, Coast Province, Kenya. Agroforestry Systems 14:193-205.

Jama, B., A. Getahun and D.N. Ngugi. 1991. Shading effects of alley cropped Leucaena leucocephala on weed biomass and maize yield at Mtwapa, Coast Province, Kenya. Agroforestry Systems 13:1-11.

Kang, B.T. 1993. Alley cropping: past achievements and future directions. Agroforestry Systems 23:141-155.

Kandji, S.T., C.K.P.O. Ogol and A. Albrecht. 2001. Diversity of plant parasitic nematodes and their relationships with some soil physico-chemical characteristics in improved fallows in western Kenya. Applied Soil Ecology 18:143-157.

Kandji, S.T., C.K.P.O. Ogol and A. Albrecht. 2003. Crop damage by nematodes in improved-fallow fields in western Kenya. Agroforestry Systems 57:51-57.

Karachi, M. 1995. Sesbania species as potential hosts to root-knot nematode (Meloidogyne javanica) in Tanzania. Agroforestry Systems 32:119-125.

Klein, A.-M., I. Steffan-Dewenter and T. Tscharntke. 2002. Predator-prey ratios on cocoa along a land-use gradient in Indonesia. Biodiversity and Conservation 11:683-693.

Kleynhans, K.P.N., E. Van den Berg, A. Swart, M. Marais and N.H. Buckley. 1996. Plant nematodes in South Africa. Plant Protection Research Institute Handbook No. 8. Pretoria: Plant Protection Research Institute.

Koech, E.K. and R. Whitbread. 2000. Disease incidence and severity on beans in alleys between Leucaena hedgerows in Kenya. Agroforestry Systems 49:85-101.

Lawton, J.H. 1994. What do species do in ecosystems? Oikos 71:363-374. 
Letourneau, D.K. 1987. The enemies hypothesis: tritrophic interactions and vegetational diversity in tropical agroecosystems. Ecology 68:1616-1622.

Liang, W. and M. Huang. 1994. Influence of citrus orchard ground cover plants on arthropod communities in China: a review. Agriculture, Ecosystem and Environment 50:29-37.

Logan, J.W.M., R.H. Cowie and T.G. Wood. 1990. Termite (Isoptera) control in agriculture and forestry by non-chemical methods: a review. Bulletin of Entomological Research 80:309-330.

Maclean, R.H., J.A. Listinger, K. Moody and A.K. Watson. 1992. The impact of alley cropping Gliricidia sepium and Cassia spectabilis on upland rice and maize production. Agroforestry Systems 20: 213-228.

Mafongoya, P.L., K.E. Giller and C.A. Palm. 1998. Decomposition pattern and nitrogen release patterns of tree prunings and litter. Agroforestry Systems 38:77-97.

Marschner, H. 1995. Mineral Nutrition of Higher Plants. London: Academic Press.

Mattson, W.J. and R.A. Haack. 1987. The role of drought stress in provoking outbreaks of phytophagous insects. In Insect Outbreaks, ed. P. Barbosa and J.C. Schultz, 365-407. San Diego: Academic Press.

Mchowa, J.W. and D.N. Ngugi. 1994. Pest complex in agroforestry systems: the Malawi experience. Forest Ecology and Management 64:277-284.

Michaud, J.P. 1998. A review of the literature on Toxoptera citricida (Kirkaldy) (Homoptera: Aphididae). Florida Entomologist 81:37-61.

Nair, P.K.R., M.R. Rao and L.E. Buck. (eds). 2004. New Vistas in Agroforestry: A Compendium for the 1st World Agroforestry Congress. Dordrecht: Kluwer Academic Publishers.

Oerke, E.C., A. Weber, H.W. Dehne and F. Schonbeck. 1994. Conclusions and perspectives. In Crop Production and Crop Protection: Estimated Losses in Major Food and Cash Crops, ed. E.C. Oerke, H.W. Dehne, F. Schonbeck and A. Weber, 742-770. Amsterdam: Elsevier.

Ogol, C.K.P.O., J.R. Spence and A. Keddie. 1998. Natural enemy abundance and activity in maize-Leucaena Agroforestry systems in Kenya. Environmental Entomology 27:1444-1451.

Ogol, C.K.P.O., J.R. Spence and A. Keddie. 1999. Maize stem borer colonization, establishment and crop damage levels in maize-Leucaena Agroforestry systems in Kenya. Agriculture, Ecosystem and Environment 76:1-15.

Ong, C.K. and M.R. Rao. 2001. Management of complex interactions for growth resources and of biotic stresses in agroforestry. In Crop Science: Progress and Prospects, ed. J. Nosberger, H.H. Geiger and P.C. Struik, 175-190. Wallingford: CABI International.

Ong, C.K., R.M. Kho and S. Radersma. 2004. Ecological interactions in multispecies agroecosystems: concepts and rules. In Below-Ground Interactions in Tropical Agroecosystems: Concepts and Models with Multiple Plan Components, ed. M. van Noordwijk, G. Cadisch and C.K. Ong, 1-15. Wallingford: CABI Publishing.

Opondo-Mbai, M.L. 1995. Investigation of arthropods associated with agroforestry in Machakos, Kenya. D.Phil. thesis, University of Oxford.

Otsyina, R., S. Minae and P. Cooper. 1996. A never ending story: rotational woodlots for soil conservation, wood, and fodder. Agroforestry Today 8(2):8-10.

Page, S.L.J. and J. Bridge. 1993. Plant nematodes and sustainability in tropical agriculture. Experimental Agriculture 29:139-154.

Perfecto, I. and J. Vandermeer. 1996. Microclimatic changes and the indirect loss of ant diversity in a tropical agroecosystem. Oecologia 108:577-582.

Phiri, A.D.K., G.Y. Kanyama-Phiri and S. Snapp. 1999. Maize and Sesbania production in relay intercropping at three landscape positions in Malawi. Agroforestry Systems 47:153-162.

Price, P.W. 1991. The plant vigour hypothesis and herbivore attack. Oikos 62:244-251.

Rao, M.R., P.K.R. Nair and C.K. Ong. 1998. Biophysical interactions in tropical agroforestry systems. Agroforestry Systems 38:3-50.

Rao, M.R., M.P. Singh and R. Day. 2000. Insect pest problems in tropical Agroforestry systems: contributory factors and strategies for management. Agroforestry Systems 50:243-277.

Redak, R.A., A.H. Purcell, J.R.S. Lopes, M.J. Blua, R.F. Mizell and P.C. Andersen. 2004. The biology of xylem-feeding insect vectors of Xylella fastidiosa and their relation to diseases epidemiology. Annual Review of Entomology 49:243-270. 
Rhainds, M. and G. English-Loeb. 2003. Testing the resource concentration hypothesis with tarnished plant bug on strawberry: density of hosts and patch size influence the interaction between abundance of nymphs and incidence of damage. Ecological Entomology 28:348-358.

Richardson, D.M. 1998. Forestry trees as invasive aliens. Conservation Biology 12:18-26.

Rippin, M., J.P. Haggar, D. Kass and U. Kopke. 1994. Alley cropping and mulch with Erythrina poeppigiana (Walp.) O.F. Cook and Gliricidia sepium (Jacq.) Walp.: effects on maize/weed competition. Agroforestry Systems 25:119-134.

Risch, S.J., D. Andow and M.A. Altieri. 1983. Agroecosystem diversity and pest control: data, tentative conclusions, and new research directions. Environmental Entomology 12:625-629.

Root, R. 1973. Organization of plant-arthropod association in simple and diverse habitats: The fauna of collards (Brassica oleracea). Ecological Monograph 43:95-124.

Salazar, A., L.T. Szott and C.A. Palm. 1993. Crop-tree interactions in alley cropping systems on alluvial soils of the Upper Amazon basin. Agroforestry Systems 22:67-82.

Sanchez, P.A. 1999. Improved fallow come of age in the tropics. Agroforestry Systems 47:3-12.

Sangakkara, U.R., P. Stamp, A. Soldati, P.S.D.R. Bandaranayake and K.B. Attanayake. 2004. Improved short fallows: impact on weed populations and maize growth in humid tropics of Asia. In New Directions for a Diverse Planet: Proceedings of the 4th International Crop Science Congress, ed. T. Fischer, N. Turner, J. Angus, L. McIntyre, M. Robertson, A. Borrell, D. Lloyd, Australia: Regional Institute Ltd. http://www. cropscience.org.au/icsc2004/poster/2/1/1/379_sangakkaraur.htm

Schroth, G. and F.L. Sinclair (eds). 2003. Trees, Crops and Soil Fertility: Concepts and Research Methods. Wallingford: CAB International.

Schroth, G., P. Balle and R. Peltier. 1995a. Alley cropping groundnut with Gliricidia sepium in Côte d'Ivoire: effects on yields, microclimate and crop diseases. Agroforestry Systems 29:147-163.

Schroth, G., R. Olivier, P. Balle, G.M. Gnahoua, N. Kanchanakanti, B. Leduc, B. Mallet, R. Peltier and W. Zech. 1995b. Alley cropping with Gliricidia sepium on a high base status soil following forest clearing: effect on soil conditions, plant nutrition and crop yields. Agroforestry Systems 32:261-276.

Schroth, G., U. Krauss, L. Gasparotto, J.A. Duarte Aguilar and K. Vohland. 2000. Pests and diseases in agroforestry systems of the humid tropics. Agroforestry Systems 50:199-241.

Shirima, D.S., R. Otsyina, W.P. Mwangeni and J. Bridge. 2000. Effect of natural and Sesbania fallows and crop rotation on the incidence of root-knot nematodes and tobacco production in Tabora, Tanzania. International Journal of Nematology 10:49-54.

Sileshi, G. 1997. Potential biocontrol agents for the blue couch grass, Digitaria abyssinica in East Africa. International Journal of Pest Management 43:173-176.

Sileshi, G. and P.L. Mafongoya. 2002. Incidence of Mesoplatys ochroptera Stål (Coleoptera: Chrysomelidae) on Sesbania sesban in pure and mixed species fallows in eastern Zambia. Agroforestry Systems 56:225-231.

Sileshi, G. and P.L. Mafongoya. 2003. Effect of rotational fallows on abundance of soil insects and weeds in maize crops in eastern Zambia. Applied Soil Ecology 23:211-222.

Sileshi, G. and P.L. Mafongoya. 2006. Long-term effect of legume-improved fallows on soil invertebrates and maize yield in eastern Zambia. Agriculture, Ecosystems and Environment 115:69-78.

Sileshi, G., J.A. Maghembe, M.R. Rao, C.K.P.O. Ogol and S. Sithanantham. 2000. Insects feeding on Sesbania in natural stands and agroforestry systems in southern Malawi. Agroforestry Systems 49:41-52.

Sileshi, G., M. Kenis, C.K.P.O. Ogol and S. Sithanantham. 2001. Predators of Mesoplatys ochroptera Stål in Sebania-planted fallows in eastern Zambia. BioControl 46:289-310.

Sileshi, G., P.L. Mafongoya, F. Kwesiga and P. Nkunika. 2005. Termite damage to maize grown in agroforestry systems, traditional fallows and monoculture on nitrogen-limited soils in eastern Zambia. Agricultural and Forest Entomology 7:61-69.

Sileshi, G., E. Kuntashula and P.L. Mafongoya. 2006. Legume improved fallows reduce weed problems in maize in eastern Zambia. Zambia Journal of Agriculture 9: (In press)

Speight, M.R., M.D. Hunter and A.D. Watt. 1999. Ecology of Insects: Concepts and Applications. Oxford: Blackwell Science Ltd.

Traoré, S. and I. Quedraogo. 1997. Influence of the microclimate on the dispersion of MSV vector leafhopper (Cicadulina spp.) in Burkina Faso. In Proceedings International Conference on Pests in Agriculture, La Corum, Montpellier, vol. 3, 927-934. France: Associacion Nacionale pour la Protection des Plantes. Vandermeer, J. 1989. The Ecology of Intercropping. Cambridge: Cambridge University Press. 
Vandermeer, J.H. and I. Perfecto. 1998. Biodiversity and pest control in agroforestry systems. Agroforestry Forum 9:2-6.

Vandermeer, J., I. Perfecto, G.I. Nun̆ez, S. Phillpott and A.G. Ballinas. 2002. Ants (Azteca sp.) as potential biological control agents in shade coffee production in Chiapas, Mexico. Agroforestry Systems 56:271-276.

van Kammen, A., J. van Lent and J. Wellink. 2001. Cowpea mosaic virus. http://www.dpvweb.net/dpv/showdpv.php?dpvno $=378$

van Noordwijk, M., G. Cadisch and C.K. Ong. 2004. Below-Ground Interactions in Tropical Agroecosystems: Concepts and Models with Multiple Plan Components. Wallingford: CABI Publishing.

Way, M.J. and C.K. Khoo. 1999 Colony dispersion and nesting habits of the ants, Dolichoderus thoracicus and Oecophylla smaragdina (Hymenoptera: Formicidae), in relation to their success as biological control agents on cocoa. Bulletin of Entomological Research 81:341-350.

West, C. 1985. Factors underlying the late season appearance of the lepidopterous leaf-mining guild on oak. Ecological Entomology 10:111-120.

White, T.C.R. 1984. The abundance of vertebrate herbivores in relation to the availability of nitrogen in stressed food plants. Oecologia 63:90-105.

Yamoah, C.F. and J.R. Burleigh. 1990. Alley cropping Sesbania sesban (L) Merill with food crops in the highlands region of Rwanda. Agroforestry System 10:169-181.

Yamoah, C.F., A.A. Agboola and K. Mulongoy. 1986. Decomposition, nitrogen release and weed control by prunings of selected Alley cropping shrubs. Agroforestry System 4:239-246.

\section{AUTHOR QUERIES}

[AQ1] The year " 2000 " has been changed to "2002" in the reference "Girma (2000)" as per the list. Please check if this is correct.

[AQ2] The year "1991" has been changed to "1990" in the reference "Way and Khoo (1991)" as per the list. Please check if this is correct.

[AQ3] Please update the reference "Sileshi (2006)." 